\title{
EFFECT OF MODIFYING AGGREGATES BY RAP AND THE SIMULTANEOUS USE OF ADHESIVES FOR THE STABILIZATION OF A SANDY PAVEMENT SUBGRADE
}

\author{
Mohammad Mehdi KHABIRI*1, Bahareh EBRAHIMIALAVIJEH ${ }^{1}$
}

\section{Abstract}

The improvement, reconstruction and repair of roads in recent years have increased the content of recycled asphalt in pavements. Using these materials in road construction projects because they reduce the costs, will also be of great help in improving environmental issues. In the present study, dune sand, which can be found in most desert area soil but does not have proper strength and loading capacity for a subgrade, was used. In order to increase the strength parameters of dune sand, various contents of cement and recycled asphalt were examined in California Bearing Ratio (CBR) and compressive strength tests. The results showed that the addition of cement and recycled asphalt can increase compressive strength and bearing capacity and reduce rupture deformations. In a stabilized sample with $27.5 \%$ recycled asphalt, increasing the cement from 7.5 to $12.5 \%$ increased the compressive strength by 1.045 times, which is the highest amount of change in the samples studied. The maximum CBR and minimum rupture deformations are related to $35 \%$ of the recycled asphalt and $12.5 \%$ of the cement. The predicted functions of the compressive strength, deformation and CBR depend on two variables of the cement content; the recycled asphalt was then calculated using the response surface method

\section{Address}

1 Civil Engineering Department, Yazd University, Yazd, Iran

* Corresponding author: mkhabiri@yazd.ac.ir

\section{Key words}

- Dune sand,

- Cement, RAP,

- Response surface method,

- Soil stabilization.

\section{INTRODUCTION}

Stabilizing soil and improving soil strength parameters in order to use it in road construction are widely discussed topics in civil engineering. Stabilizing materials that have been used by various researchers for improving soil and increasing the soil's bearing capacity include cement, lime and some polymer materials (Liu et al. 2019; J. Muhammed, 2019; Khabiri, 2010; Rezaeimalaek et al.2017; Kumar, et al. 2019). A lime-silica fume mix in dune sand will increase the adhesion and angle of the friction (Fattah et al.2016) and, in collapsible soils, can lead in decreasing potential collapses and increasing the bearing capacity (Fattah et al.2016). Using cement kiln dust can increase the shear strength and bearing capacity in sand (Albusoda and Salem, 2012) and can increase the compressive strength and bearing capacity in oil-contaminated sand (Nasr 2014). In regions which are in danger of sulfate attacks, cement with a lower aluminate content performs better in stabilizing the sand soil (Liu et al.2019). The addition of cement to soil increases the compressive strength, shear strength, and bearing capacity of the soil and also increases the brittleness of soil (Jamshidi Chenari 2018). Increased compressive and tensile strength with the addition of various types of cement have also been reported. Using fiber in stabilized soil with cement not only improves soil strength parameters, but also increases the rupture strains and makes the sample ductile (Estabragh et al. 2017; Saberian and Khabiri 2018; Malidarreh et al. 2017).

Expanding the use of recycled materials and industrial waste as building materials in construction projects as material for stabilizing 
subgrade soil is a suitable solution, both economically and environmentally. One of these waste materials is pavement asphalt. In order to increase the efficiency of road pavements or eliminate the existence of damage on a pavement surface, repairing and reconstructing of a pavement is essential, it can lead to increases in the content of pavement asphalt. Reusing these materials in road construction reduces the operating cost of projects and helps to improve environmental effects (Faysal et al. 2016). Using recycled pavement asphalt in bed soil increases the soil's elasticity module, which indicates the suitability of this mixture for stabilizing road bed soil (Hasan et al. 2018). Adresi et al. (2018) investigated the effect of the addition of recycled asphalt on a stabilized layer with cement. In wet samples (which were tested for simulating winter conditions at a temperature of $25^{\circ} \mathrm{C}$ ), increasing the recycled asphalt content and cement content reduced and increased the compressive strength, respectively. Similar results were observed in a mixture of recycled asphalt and crushed stone material stabilized with cement (Dokovic et al. 2019) and sand or gravel stabilized by cement and recycled asphalt (Ghanizadeh et al. 2018). Increasing the content of recycled asphalt reduced the value of CBR. Accordingly, Mousa et al. (2017) recommended a content of recycled asphalt of $60 \%$ and $20 \%$ for the subbase and base layers, respectively. The addition of recycled asphalt to soil can lead to an increase in the tensile strength of soil (Isola et al. 2013). A mixture of recycled asphalt and intact aggregate stabilized with cement is an appropriate option for an application to the base layer in road construction (Taha et al. 2002). Using recycled asphalt pavement materials while creating a flexible pavement increased the compressive strength, elasticity module and CBR (Li et al. 2008). Alhaji and Alhassan (2018) used recycled pavement asphalt for stabilizing loose black clay. The results showed that the addition of recycled asphalt decreased the potential inflation. By increasing the content of recycled asphalt up to $30 \%$, the compressive strength and elasticity module were first increased and were higher than the amount they decreased. The addition of recycled pavement asphalt in loose black clay soil increased the California bearing ratio and made this soil appropriate for use in a subbase layer in light traffic (Alhaji and Alhassan, 2018). The use of recycled asphalt in sand increased the soil's strength in undrained cyclic triaxial tests (Yokohama and Sato, 2019). Dune sand is a soil which does not have proper bearing capacity as subgrade soil (Tiwari et al. 2016). Given that a part of the available land for construction in a desert area is sand dune soil, addressing the issues related to the improvement and increasing the strength of these type of soils seems necessary. In the present study, the stabilization of this soil by mixing it with cement and recycled asphalt was investigated in order to increase the efficiency of sand dune soil. The compressive strength, deformations in ruptures as well as the California bearing ratio of the stabilized sand samples were measured with different contents of cement and recycled asphalt. Using the response surface method, the functions of compressive strength, deformation in rupture, and CBR in terms of recycled asphalt and cement content were calculated.

\section{MATERIALS}

\subsection{Soil}

The soil used in the present study is categorized in the fine sand class (A-3) based on the AASHTO classification. After performing soil identification tests, the particle size distribution graph and some of the mechanical properties of the soil tested, were shown in Fig. 1 and Table 1, respectively. Fig. 2 shows an image of the sand used and the amount of earthwork related to the construction of a road and pavement. A compaction test was repeated 5 times on the soil sample and the dry density and moisture were calculated. The dry density in terms of the moisture shown in Fig.1, the maximum dry moisture and the optimum moisture were calculated from the test and are shown in Table 1.

Table 1. Specification of the soil used in the research.

\begin{tabular}{cccc}
\hline Parameter & Content & Unit & Standard used \\
\hline Soil classification & A-3 & - & AASHTO \\
\hline $\mathrm{G}_{\mathrm{s}}$ & 2.7 & - & ASTM D-854 \\
\hline $\mathrm{CBR}$ & 19 & $(\%)$ & ASTM D-1883 \\
\hline $\mathrm{C}$ & 0.1 & $(\mathrm{kPa})$ & ASTM D-3080 \\
\hline & 46 & $(\mathrm{degree})$ & ASTM D-3080 \\
\hline & 16 & $(\%)$ & ASTM D-698 \\
\hline & 1.845 & $\left(\mathrm{gr} / \mathrm{cm}^{3}\right)$ & ASTM D-698
\end{tabular}

\subsection{Cement}

The material used in the present study to improve the strength parameters of the sand soil was cement, which was added to the soil with $7.5 \%, 10 \%$ and $12.5 \%$ by dry weight of the soil. These cement

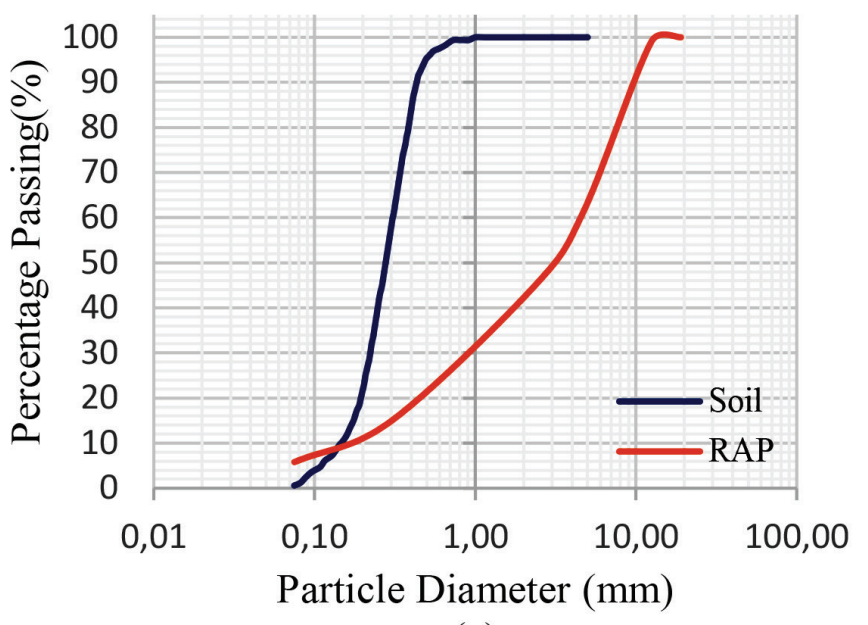

(a)

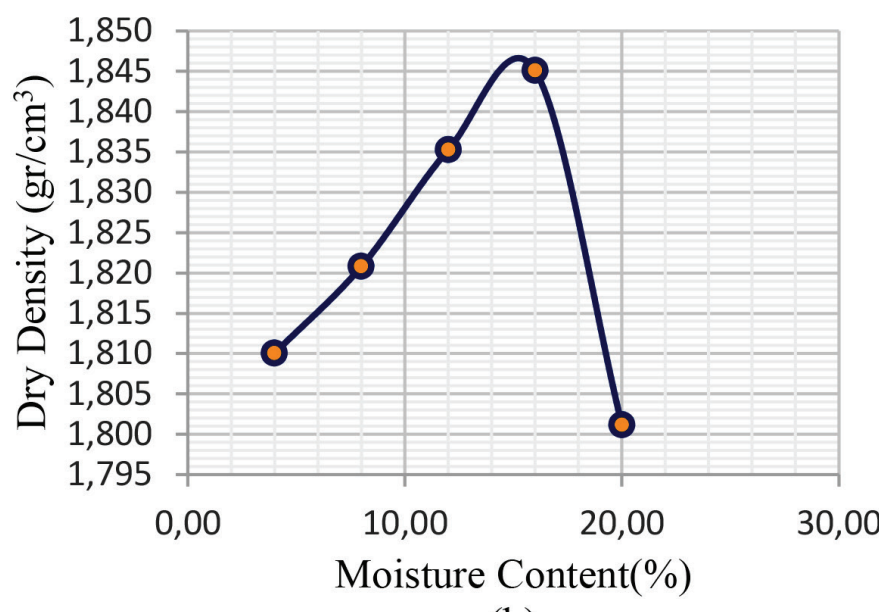

(b)

Fig 1. (a) Particle size distribution graph and (b) soil compaction curve used in the research. 


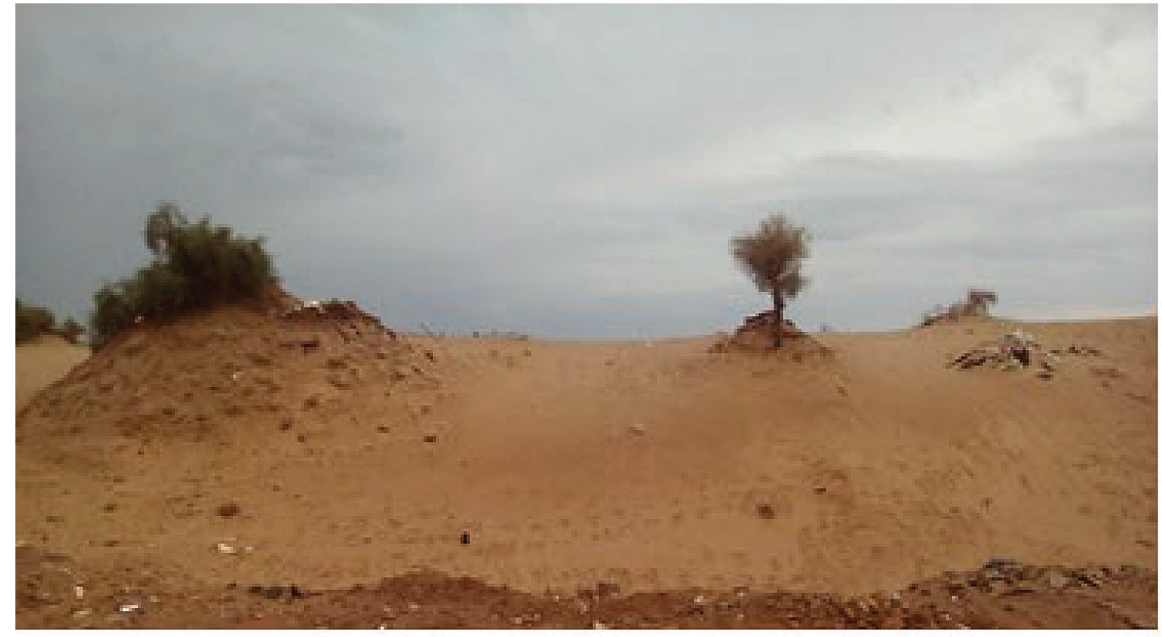

(a)

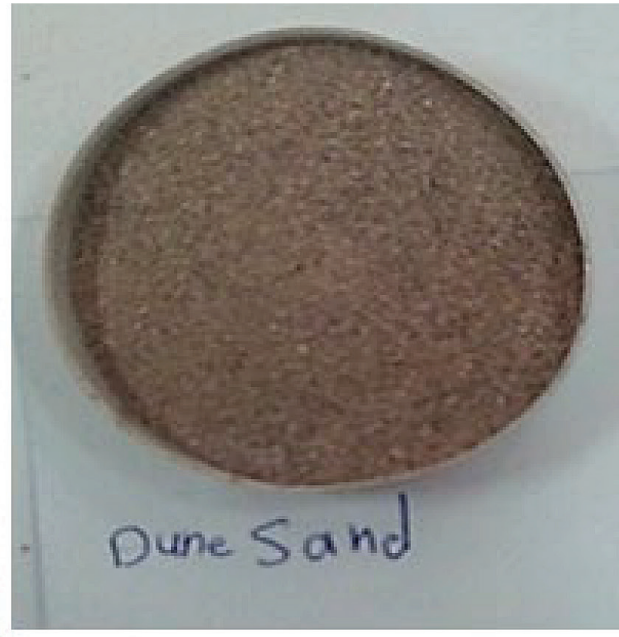

(b)

Fig 2. (a) The location of the removed sand sample and earthwork volume (b) sand sample.

contents have been used by other researchers (Caro et al. 2018). Fig. 3 shows an image of the cement used in this study. The physical and chemical specifications of the cement used in the present study are shown in Tables 2 and 3, respectively.

Table 2. Chemical specification of Portland cement Type 2 used in the test.

\begin{tabular}{|c|c|}
\hline Chemical properties & Content (\%) \\
\hline $\mathrm{SiO}_{2}$ & 20 \\
\hline $\mathrm{Al}_{2} \mathrm{O}_{3}$ & 6 \\
\hline $\mathrm{Fe}_{2} \mathrm{O}_{3}$ & 6 \\
\hline $\mathrm{MgO}$ & 5 \\
\hline $\mathrm{SO}_{3}$ & 3 \\
\hline Weight loss due to frying & 3 \\
\hline Insoluble residue & 0.75 \\
\hline $\mathrm{C}_{3} \mathrm{~A}$ & 8 \\
\hline
\end{tabular}

Table 3. Physical specification of Portland cement Type 2 used in the test.

\begin{tabular}{|c|c|c|}
\hline Physical properties & \multicolumn{2}{|c|}{ Value } \\
\hline Specific area of $1 \mathrm{~cm}^{2} / \mathrm{gr}$ & \multicolumn{2}{|c|}{2800} \\
\hline Expansion of autoclave test (\%) & \multicolumn{2}{|c|}{0.8} \\
\hline \multirow{2}{*}{$\begin{array}{l}\text { Setting time with the Vicat } \\
\text { method }\end{array}$} & Initial (min) & 45 \\
\hline & Final (hour) & 6 \\
\hline \multirow{3}{*}{ Compressive strength $\left(\mathrm{kg} / \mathrm{cm}^{2}\right)$} & 3 day & 100 \\
\hline & 7 day & 175 \\
\hline & 28 day & 315 \\
\hline Hydration heat (Cal/gr) & & 70 \\
\hline
\end{tabular}

\subsection{Recycled asphalt}

Another stabilizer material is recycled asphalt, which was added to the soil with $20 \%, 27.5 \%$ and $35 \%$ by dry weight of soil. After

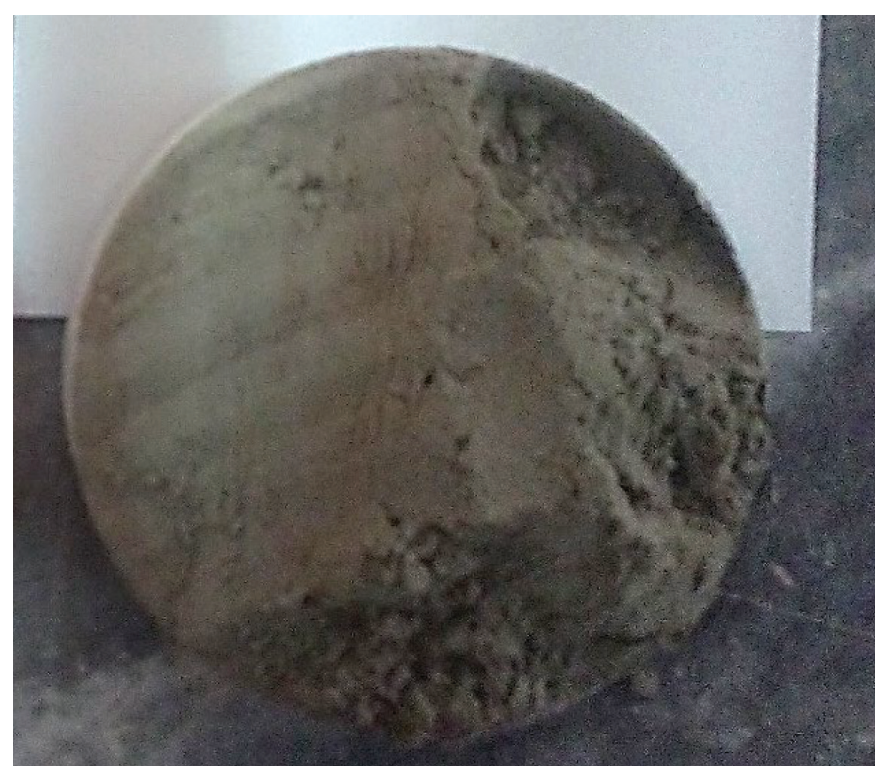

Fig 3. A sample of the cement used in the tests.

separating the bitumen, the available aggregations were graded; the aggregation curve is shown in Fig. 1(a). The content of bitumen available in the recycled asphalt studied and based on the ASTM D-2172 standard was 5.5 percent. An image of the recycled asphalt is shown in Fig. 4.

\section{METHODOLOGY}

In the present study, the stability of the dune sand soil using cement and recycled asphalt was investigated. In order to be informed of the positive effects of this type of improvement in road construction, given the available loadings in road paths, the determination of the compressive strength, the value of deformation in the rupture and the bearing capacity call for the necessary tests. In the compressive strength test for creating samples, the ASTM C-109 standard was used. An investigation of the bearing capacity is an effective and important parameter in pavement and road construction. The compressive strength and the value of deformations in the rupture were measured using a $2 \mathrm{kN}$ loading device. For this purpose, the CBR test 

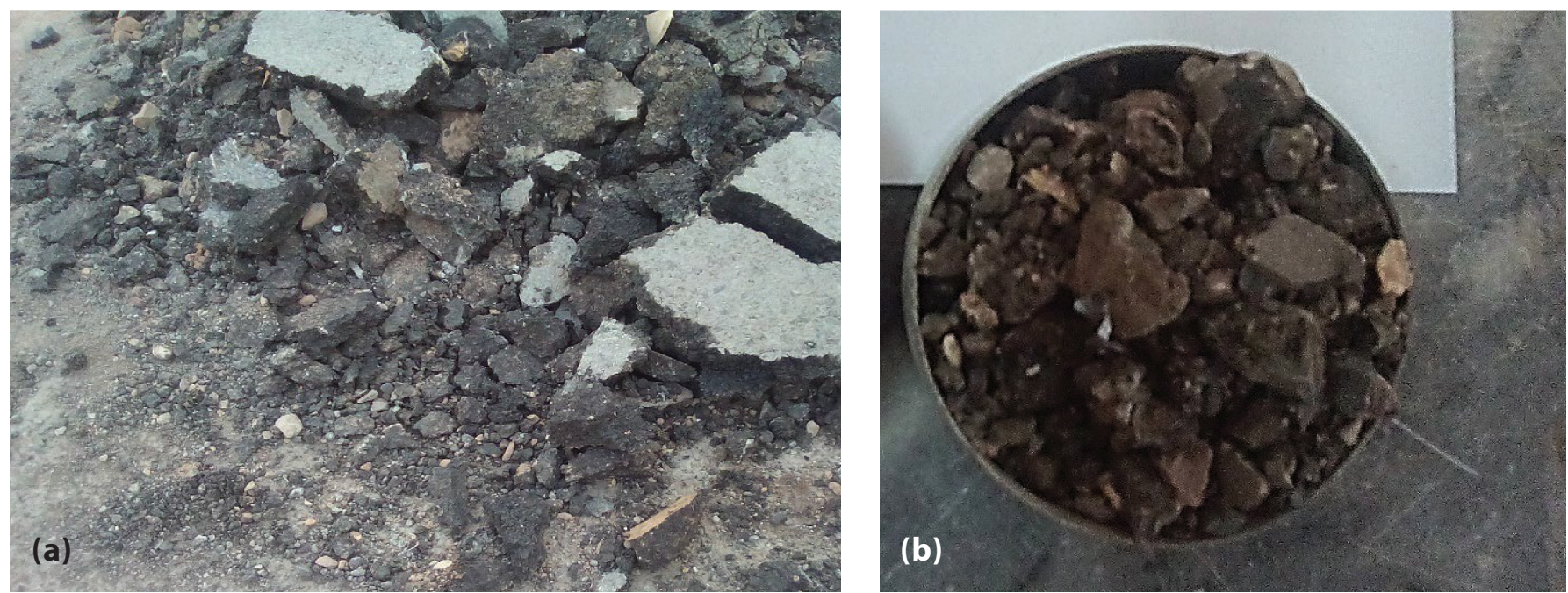

Fig 4. (a) Depot location of recycled asphalt and (b) recycled asphalt used in stabilizing the dune sand soil.

was used based on the ASTM D-1883 standard with different contents of recycled asphalt and cement. After performing the required tests using the response surface method and Design Expert software, the predictive functions of the compressive strength, deformation in the ruptures, and CBR were calculated. The variables of these functions were the amount of cement and recycled asphalt.

\subsection{Preparation of the samples}

The compressive strength test, measuring deformations in the ruptures, and the California bearing capacity test were performed with different contents of cement and recycled asphalt. Recycled asphalt with $20 \%, 27.5 \%$ and $35 \%$ by dry weight of the soil and cement with $7.5 \%, 10 \%$ and $12.5 \%$ by dry weight of the soil were added to the dry soil. The cement and recycle asphalt were weighed and used (by dry weight of soil) for constructing the sample, given the moisture content and dry density calculated in the compaction test, These materials were mixed with water in order that a uniform and homogeneous mixture could be obtained. The mixture obtained was poured in the mold and compressed. For curing the cement, the samples were maintained in a closed environment and were then tested. Fig. 5 shows an image of the samples used in the test.

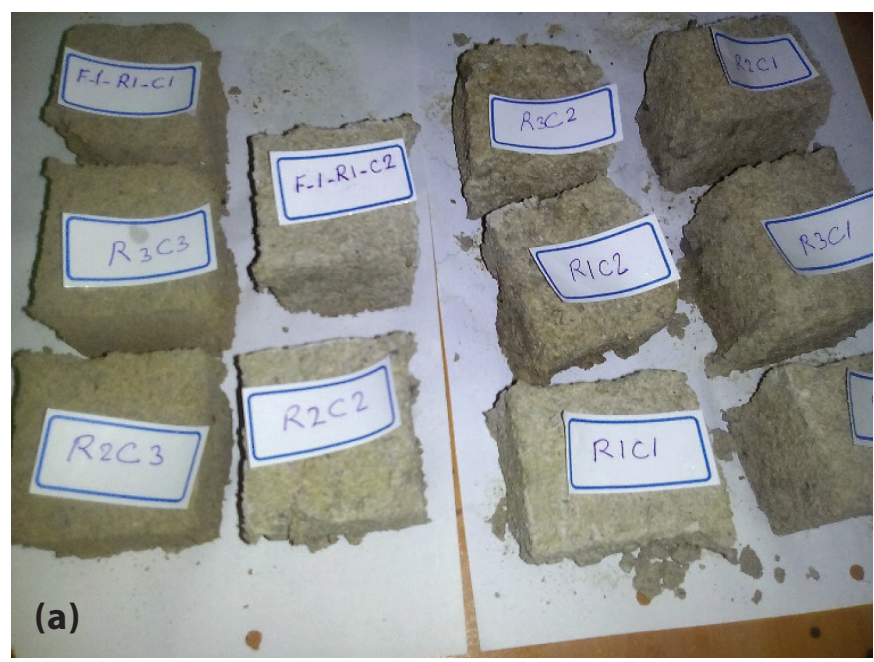

\section{RESULTS AND DISCUSSION}

\subsection{Deformation and compressive strength test}

The stabilized samples with cement and recycled asphalt were tested under compressive force and compressive strength tests, and the amounts of deformations in the ruptures were recorded. As can be seen from Fig. 6, increasing the cement content at a fixed recycled asphalt percentage led to an increase in the compressive strength. The maximum variations in the stabilized samples were seen in $27.5 \%$ of the recycled asphalt, so that by increasing the cement content from $7.5 \%$ to $12.5 \%$, the compressive strength increased 1.045 times. At a fixed cement content, increasing the recycled asphalt by up to $27.5 \%$, led to an increase in the compressive strength; after this content a reduction was observed. Therefore, the maximum compressive strength in $27.5 \%$ of the recycled asphalt and $12.5 \%$ of the cement was measured. Fig. 7 shows the deformations of the failure with different contents of cement and recycled asphalt. According to Fig. 7, increasing the cement and recycled asphalt can decrease the deformation rate. Therefore, the minimum deformation rate at the failure moment is related to the sample stabilized with $12.5 \%$ of cement and $35 \%$ of recycled asphalt. The increase in cement will

Fig 5. (a) Dune sand soil samples stabilized with cement and recycled asphalt. (b) Close-up view of stabilized soil. 


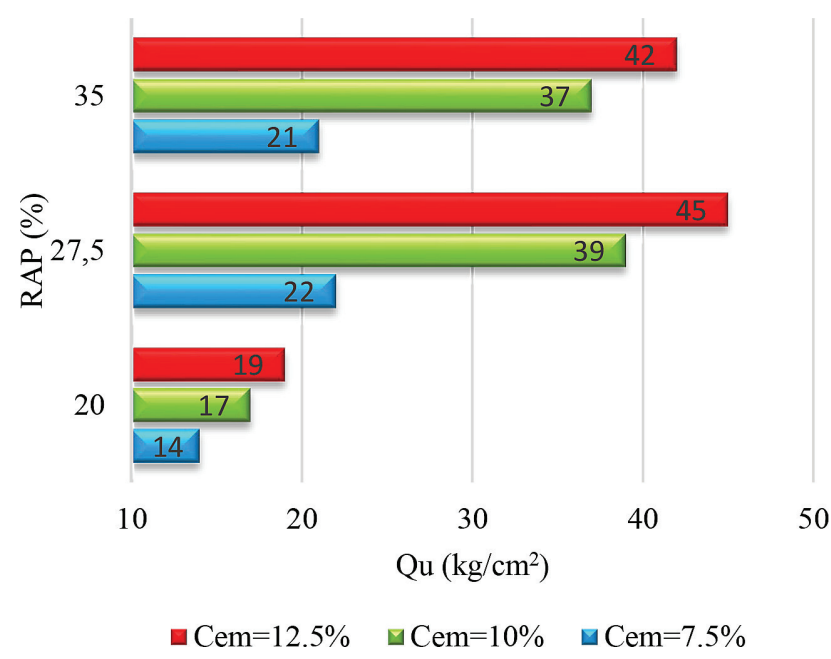

Fig 6. The effect of RAP content (recycled asphalt) on the compressive strength with different cement contents.

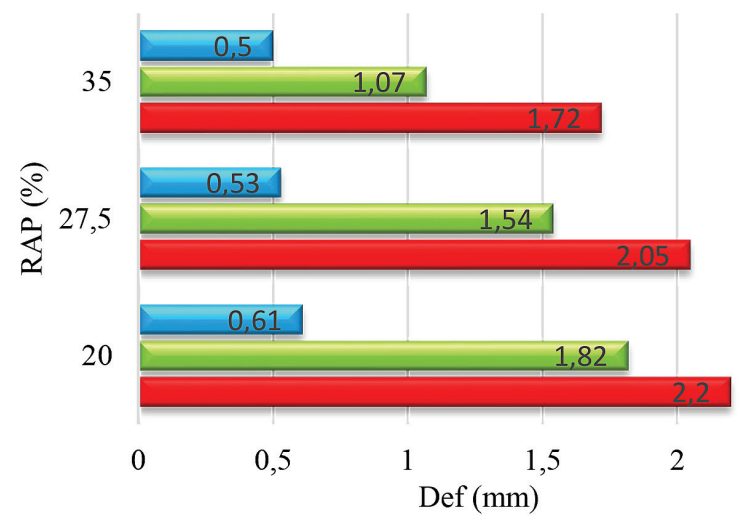

$\square \mathrm{Cem}=12.5 \% \quad \square \mathrm{Cem}=10 \% \quad \square \mathrm{Cem}=7.5 \%$

Fig 7. The effect of RAP content on the deformation at the moment failure with different cement contents.

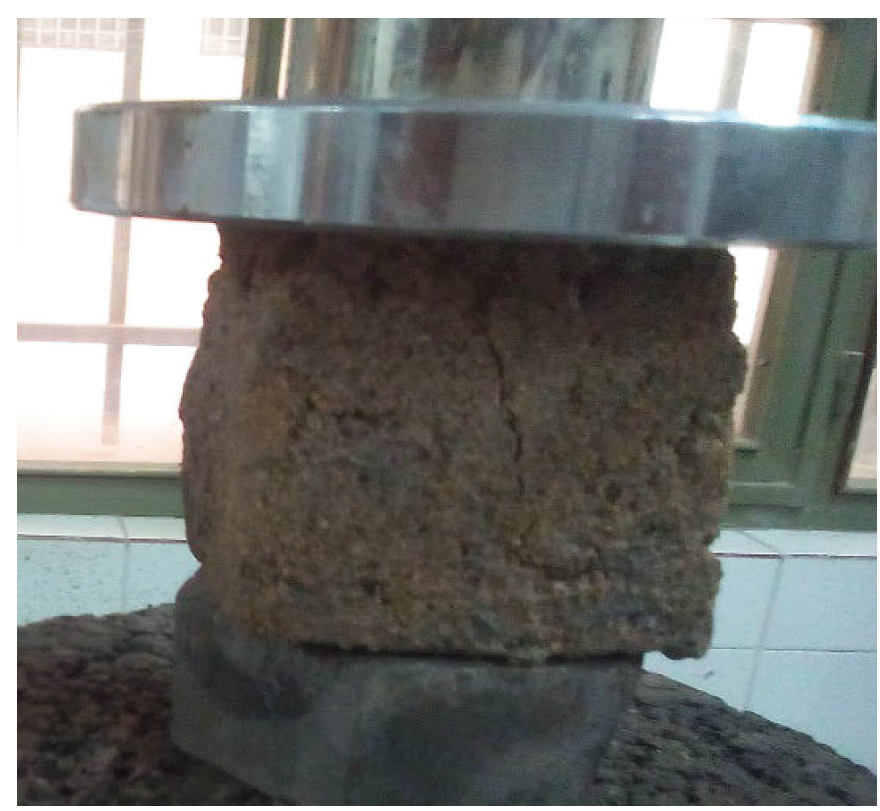

Fig 8. Stabilized sample after the compressive strength test. increase the adhesion and the coherence between the soil particles and asphalt. This factor probably reduced the deformation rate of the sample at the failure moment, and it can be seen in Fig. 7 that the increase in cement has a greater effect on the reduction of the deformation rate of the samples than the increase in the amount of the recycled asphalt. The stabilized sand soil sample is shown after its failure.

\subsection{CBR test results}

A test that is important in road construction projects is the CBR test and the determination of the soil bearing capacity of the subgrade. A CBR test was performed with different cements and recycled asphalt contents for the stabilized samples. Fig. 9 shows the CBR variations due to the variations in the content of the stabilizer materials. At a fixed cement content, increasing the recycled asphalt content increased the California bearing ratio. Similar results were observed with the constant recycled asphalt with an increase in the cement content. It is noteworthy however that the increased rate of CBR due to the increase in the cement content is higher than the recycled asphalt. In the stabilized sample with $20 \%$ of the recycled asphalt, by increasing the cement content from 7.5 to $12.5 \%$, the California bearing ratio increased 1.714 times. The maximum content of CBR was obtained in the stabilized sample with $35 \%$ of the recycled asphalt and $12.5 \%$ of the cement.

\subsection{Analysis of the response surface}

The response surface method was used with Design Expert software for predicting the compressive strength function, the deformation at the moment of failure and the CBR two related variables, including the recycled asphalt and cement contents. The recommended function of the software for all three variables is of the second order type. Table 4 shows the recommended second order function and the regression value. Three dimensional views of the variation of the compressive strength, deformation at the moment of failure, and the CBR with different cement and recycled asphalt contents are shown in Figs. 10-12, respectively.

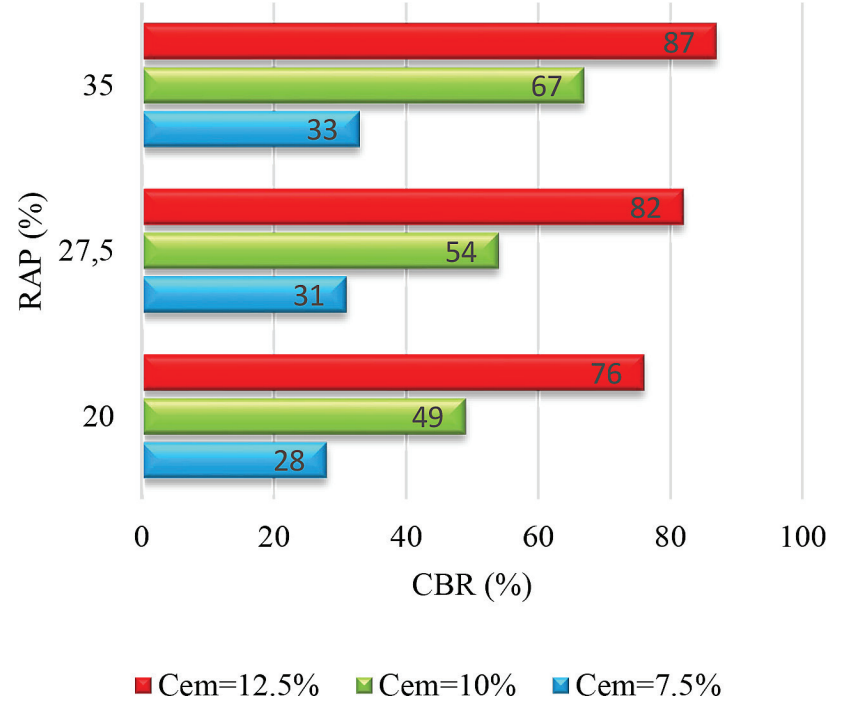

Fig 9. The effect of RAP content on the CBR with different cement contents. 
Table 4. Recommended function of the response surface method.

\begin{tabular}{|c|c|c|}
\hline Variable & Suggested Functions & $\mathrm{R}$ - square \\
\hline $\mathrm{Q}_{\mathrm{u}}\left(\mathrm{kg} / \mathrm{cm}^{2}\right)$ & $\begin{array}{c}-179.69732+(11.13793 \times \mathrm{Cem})+(9.53103 \times \mathrm{RAP})+(0.21333 \times \mathrm{Cem} \times \mathrm{RAP}) \\
-\left(0.6869 \times \mathrm{Cem}^{2}\right)-\left(0.19188 \times \mathrm{RAP}^{2}\right)\end{array}$ & 0.9689 \\
\hline $\operatorname{Def}(\mathrm{mm})$ & $\begin{aligned} & 2.20479+(0.27911 \times \mathrm{Cem})-(0.015724 \times \mathrm{RAP}) \\
&\left.+\left(4.93333 \times 10^{-3}\right) \times \mathrm{Cem} \times \mathrm{RAP}\right)-\left(0.035172 \times \mathrm{Cem}^{2}\right) \\
&\left.-\left(1.15249 \times 10^{-3}\right) \times \mathrm{RAP}^{2}\right)\end{aligned}$ & 0.9796 \\
\hline CBR (\%) & $\begin{array}{c}18.76832+(2.80067 \times \mathrm{Cem})-(2.88270 \times \mathrm{RAP})+(0.12531 \times \mathrm{Cem} \times \mathrm{RAP}) \\
+\left(0.19458 \times \mathrm{Cem}^{2}\right)+\left(0.043024 \times \mathrm{RAP}^{2}\right)\end{array}$ & 0.9897 \\
\hline
\end{tabular}

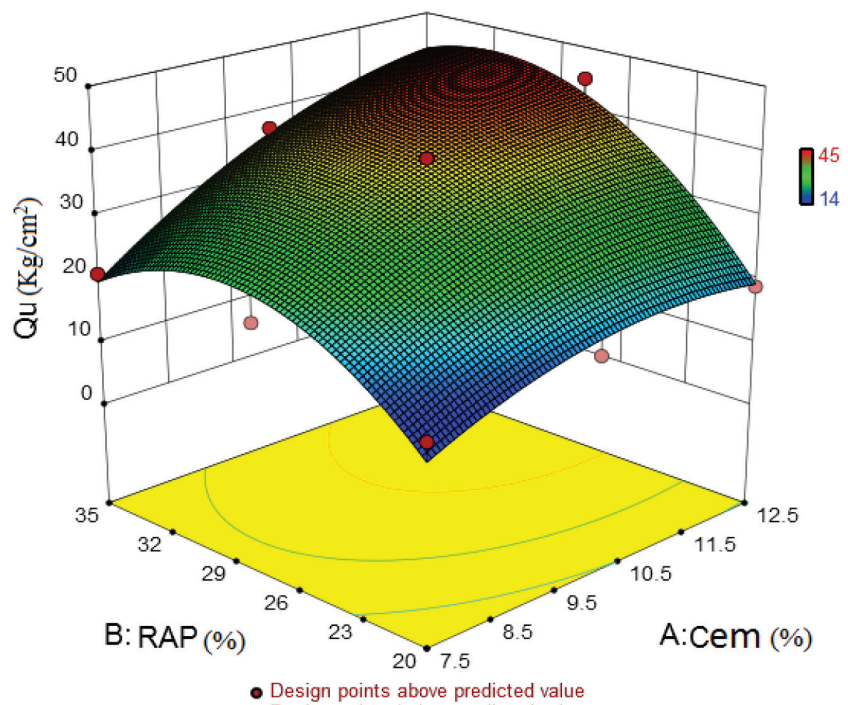

Fig 10. 3D display of the simultaneous effects of cement and recycled asphalt on the compressive strength.

\section{CONCLUSION}

The California bearing ratio and compressive test for various cement and recycled asphalt contents were performed in order to study the stability of dune sand soil using cement and recycled asphalt. The results of the compressive strength, deformation rate at the moment of failure, and the CBR rate of the samples show that:

1. At a fixed recycled asphalt content, increasing the cement content increased the compressive strength, where most of the changes were related to the samples stabilized with $27.5 \%$ of recycled asphalt, which increased the compressive strength 1.045 times. Also, with a fixed cement content, the increase in the recycled asphalt up to $27.5 \%$ increased the strength; subsequently, a reduction was observed.

2. By increasing the cement and recycled asphalt, the deformation rate at the moment of failure decreased. The minimum deformation rate at the moment of failure was related to the sample stabilized with $35 \%$ of the recycled asphalt and $12.5 \%$ of cement. The cement had a greater role in reducing deformation rate of the samples than the recycled asphalt.

3. The maximum measured CBR is related to the samples stabilized with $35 \%$ recycled asphalt and $12.5 \%$ of cement. Therefore, increasing both the cement and recycled asphalt content increased the California bearing ratio.

4. In order to predict the compressive strength function, deformation at the moment of failure and the California bearing ratio, the response surface method was used. The recommended function is of the second order type, where the regression obtained was higher than 0.96 for all three functions, which indicated an acceptable level of precision of the function calculated.

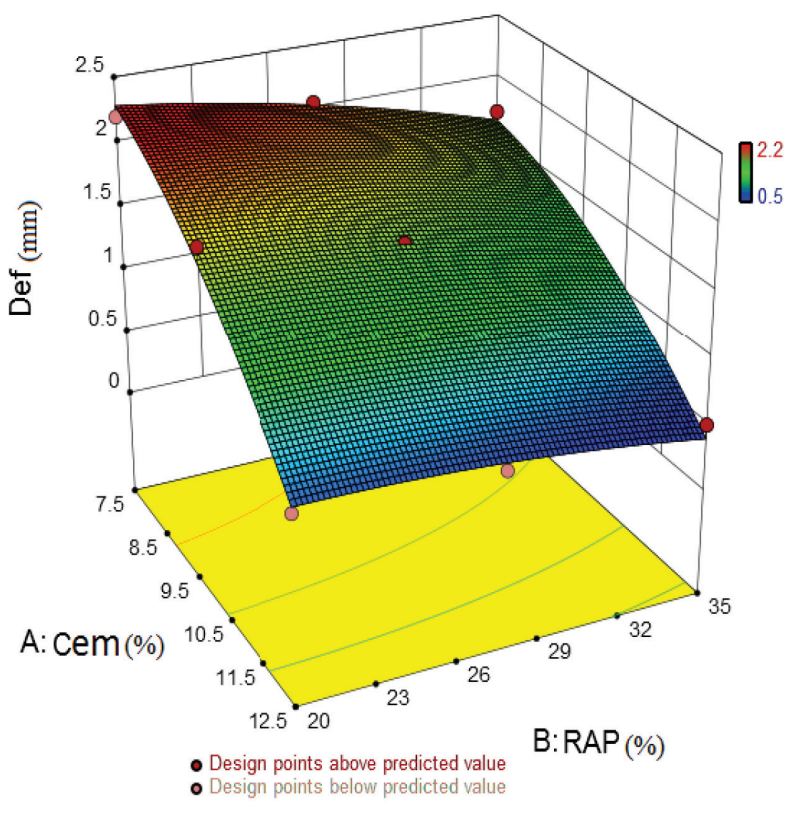

Fig 11. 3D display of simultaneous effects of cement and recycled asphalt on deformations in the rapture moment.

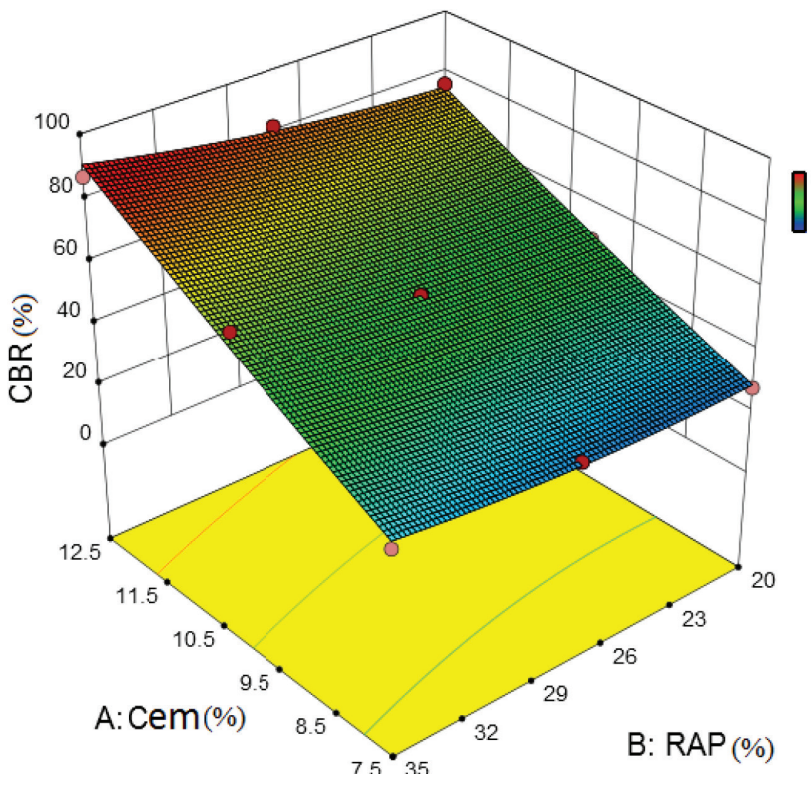

Fig 12. 3D display of the simultaneous effects of the cement and recycled asphalt on the $C B R$. 


\section{REFERENCES}

AASHTO M-145, Standard specification for classification of soils and soil-aggregate mixtures for highway construction purposes.

ASTM D-1883, Standard test method for California Bearing Ratio (CBR) of laboratory-compacted soils.

ASTM C109 / C109M, Standard test method for compressive strength of hydraulic cement mortars (using 2-in. or [50-mm] cube specimens).

ASTM D-3080. Standard test method for direct shear test of soils under consolidated drained conditions.

ASTM D-698, Standard test methods for laboratory compaction characteristics of soil using standard efforts $(12,400 \mathrm{ft}-\mathrm{lbf} / \mathrm{ft} 3$ (600 kN-m/m3).

ASTM D-854, Standard test methods for specific gravity of soil solids by water pycnometer

Ateş A. (2016), Mechanical properties of sandy soils reinforced with cement and randomly distributed glass fibers (GRC). Composites Part B: Engineering. 2016; 96: 295-304.

Adresi, M. - Khishdari, A. - Ahmadi, A. - Rooholamini, H. (2019). Influence of high content of reclaimed asphalt on the mechanical properties of cement-treated base under critical environmental conditions. International Journal of Pavement Engineering, 20(9), 1098-1105.

Albusoda, B. S. - Salem, L. A. - Salem, K. (2012). Stabilization of dune sand by using cement kiln dust (CKD). Journal of Earth Sciences and Geotechnical Engineering, 2(1), 131-143.

Alhaji, M. M. - Alhassan, M. (2018). Free swelling and modulus of elasticity of compacted black cotton soil treated with reclaimed asphalt pavement. The Egyptian International Journal of Engineering Sciences \& Technology, 25, 60-67.

Alhaji, M. M. - Alhassan, M. (2018). Effect of reclaimed asphalt pavement stabilization on the microstructure and strength of black cotton soil. International Journal of Technology, 9(4), 727-736.

Caro, S. - Agudelo, J. P. - Caicedo, B. - Orozco, L. F. - Patiño, F. - Rodado, N. (2018). Advanced characterisation of cement-stabilized lateritic soils to be used as road materials. International Journal of Pavement Engineering, 1-10.

Đoković, K. - Tošović, S. - Janković, K. - Šušić, N. (2019). Physical-Mechanical Properties of Cement Stabilized RAP/Crushed Stone Aggregate Mixtures. Tehnički vjesnik, 26(2), 385-390.

Edeh, J. E. - Eberemu, A. O. - Abah, A. B. (2012). Reclaimed asphalt pavements-lime stabilization of clay as highway pavement materials. Journal of Sustainable Development and Environmental Protection, 2(3), 62-75.

Estabragh, A. R. - Ranjbari, S. - Javadi, A. A. (2017, January). Properties of clay soil and soil cement reinforced with polypropylene fibers. American Concrete Institute.

Fattah, M. Y - Joni, H. H. - Al-Dulaimy, A. S. (2018). Strength characteristics of dune sand stabilized with lime-silica fume mix. International Journal of Pavement Engineering, 19(10), 874-882.

Faysal, M. - Mahedi, M. - Aramoon, A. - Thian, B. - Hossain, M. S. - Khan, M. S. (2016). Strength characterization of untreated and cement-treated recycled flex-base materials. In Geotechnical and Structural Engineering Congress 2016 (pp. 1233-1244).

Ghanizadeh, A. R. - Rahrovan, M. - Bafghi, K. B. (2018). The effect of cement and reclaimed asphalt pavement on the mechanical properties of stabilized base via full-depth reclamation. Construction and Building Materials, 161, 165-174.

Haeri, S. M. - Hamidi, A. - Hosseini, S. M. - Asghari, E. - Toll, D. G. (2006). Effect of cement type on the mechanical behavior of a gravely sand. Geotechnical \& Geological Engineering, 24(2), 335.

Hasan, M. M. - Islam, M. R. - Tarefder, R. A. (2018). Characterization of subgrade soil mixed with recycled asphalt pavement. Journal of Traffic and Transportation Engineering (English edition), 5(3), 207-214.

Isola, M. - Betti, G. - Marradi, A. - Tebaldi, G. (2013). Evaluation of cement treated mixtures with high percentage of reclaimed asphalt pavement. Construction and Building Materials, 48, 238-247.

Jamshidi Chenari, R. J. - Fatahi, B., Ghorbani, A. - Alamoti, M. N. (2018). Evaluation of strength properties of cement stabilized sand mixed with EPS beads and fly ash. Geomechanics and Engineering, 14(6), 533-544.

Khabiri, M. M. (2010). The effect of stabilized subbase containing waste construction materials on reduction of pavement rutting depth. Electronic Journal of Geotechnical Engineering, 15, 1211-1219.

Kumar, A. - Soni, D. K. (2019), Study of the mechanical behaviour of a clayey soil under normal and frozen conditions. Slovak Journal of Civil Engineering, Vol. 27, 2019, No. 1, 29 - 35.

Li, L., Benson - C. H., Edil, T. B. - Hatipoglu, B. (2008). Sustainable construction case history: Fly ash stabilization of recycled asphalt pavement material. Geotechnical and Geological Engineering, 26(2), 177-187.

Liu, K. - Wang, Y. - Jiang, N. J. - Wang, A. - Sun, D. - Chen, X. (2019). Effect of aluminate content in cement on the long-term sulfate resistance of cement stabilized sand. Marine Georesources \& Geotechnology, 1-10.

Liu, Y. - Wang, Q. - Liu, S. - ShangGuan, Y. - Fu, H. - Ma, B. Chen, H. - Yuan, X. (2019). Experimental investigation of the geotechnical properties and microstructure of lime-stabilized saline soils under freeze-thaw cycling. Cold Regions Science and Technology, 161, 32-42.

Malidarreh, N. R. - Shooshpasha, I. - Mirhosseini, S. M. - Dehestani, M. (2018). Effects of reinforcement on mechanical behaviour of cement treated sand using direct shear and triaxial tests. International Journal of Geotechnical Engineering, 12(5), 491-499.

Mousa, E. - Azam, A. - El-Shabrawy, M., - El-Badawy, S. M. (2017). Laboratory characterization of reclaimed asphalt pavement for road construction in Egypt. Canadian Journal of Civil Engineering, 44(6), 417-425.

J. Muhammed, J. (2019), Deterministic and probabilistic approaches in the analysis of the bearing capacity of a bridge foundation on undrained clay soil. Slovak Journal of Civil Engineering, Vol. 27, 2019, No. 2, $44-51$. 
Nasr, A. M. (2014). Utilisation of oil-contaminated sand stabilized with cement kiln dust in the construction of rural roads. International Journal of Pavement Engineering, 15(10), 889-905.

Rezaeimalek, S. - Nasouri, A. - Huang, J. - Bin-Shafique, S. - Gilazghi, S. T. (2017). Comparison of short-term and long-term performances for polymer-stabilized sand and clay. Journal of traffic and transportation engineering (English edition), 4(2), 145-155.

Saberian, M. - Khabiri, M. M. (2018). Effect of oil pollution on function of sandy soils in protected deserts and investigation of their improvement guidelines (case study: Kalmand area, Iran). Environmental geochemistry and health, 40(1), 243-254.
Taha, R. - Al-Harthy, A. - Al-Shamsi, K. - Al-Zubeidi, M. (2002) Cement stabilization of reclaimed asphalt pavement aggregate for road bases and subbases. Journal of materials in civil engineering, 14(3), 239-245.

Tiwari, S. K. - Sharmaa, J. P. - Yadavb, J. S. (2016). Behaviour of dune sand and its stabilization techniques. Journal of Advanced Research in Applied Mechanics, 19(1), 1-15.

Yokohama, S. - Sato, A. (2019). Cyclic mechanical properties of sandy soils by mixing recycled asphalt pavement material. International Journal of GEOMATE, 16(58), 41-47. 